\title{
Multiple Project Team Membership and Performance: Empirical Evidence from Engineering Project Teams
}

\author{
Kai-Ying Chan \\ Graduate School of Technology Management, University of Pretoria
}

Accepted: December 2013

\begin{abstract}
Individuals are increasingly involved in more than one project team. This implies that an employee simultaneously has multiple memberships in these project teams, a phenomenon known as multiple team membership (MTM). Previous, predominantly theoretical studies have acknowledged the impacts that MTM has on performance but very scarce empirical evidence exists. The aim of this study is to provide empirical support for some of these theoretical claims using data collected from 435 team members in 85 engineering project teams in South Africa. Results show that MTM has an inverted-U shaped relationship with individual performance and a positive linear relationship with team performance. When a person is working in multiple project teams simultaneously, he/she may encounter more diverse sources of ideas across all teams and thus enhances his/her innovative performance. However, as the number of MTM increases, the negative effect of task switching and fragmented attention will negatively impact on individual performance. At the project team level, a large number of MTM in a focal team allows the team members to integrate diverse sources of knowledge and resources into the focal team. This study also found that individuals' emotional skills and cognitive skills impact on individual performance. It is recommended to programme and project portfolio managers, who often are involved in scheduling human resources to multiple projects, to acknowledge both the positive and negative impacts of MTM on performance. Moreover, in high MTM situations, project team members with high emotional and cognitive skills should be selected.
\end{abstract}

Key words: multiple team membership, individual performance, team performance, project teams

JEL: L2O, ZOO, D23, M12

\section{1}

\section{Introduction}

Since the 1990s modern organisations have relied more and more on project-based structures (Whittington, Pettigrew, Peck, Fenton \& Conyon, 1999). Projects can be defined as temporary rather than permanent social systems that are constituted of teams (governed by mechanisms of trust and control) to accomplish particular tasks (in order to meet project goals) under time constraints" (Manning, 2008:31). Moreover, empirical evidence shows that up to 90 per cent of all projects are carried out concurrently in a multi-project context (Payne, 1995). In order to utilize resources more efficiently, the same resource or individual may be allocated across multiple projects. Studies have shown that individuals who work in teams are often involved in more than one (project) team at the same time (Chudoba, Wynn, Lu \& WatsonManheim, 2005; O’Leary, Wooley \& Mortensen,
2011) and this simultaneous involvement in multiple project teams by an individual is known as "multiple team membership" (MTM) (O'Leary et al, 2011). As the number of project teams that an individual is simultaneously involved in (MTM) increases, there are various benefits and challenges. For example, Edmondson and Nembhard (2009) mention that team members need time to get acquainted with each other before they can work together effectively as a team. This implies that by being involved in multiple teams, an individual has the repeated opportunities to learn "to team-up" and to build swift trust with new members. However, too many team memberships can increase a person's stress level (such as burn-out) due to working excessive hours in meeting the demands of various leaders or clients across projects. As a result, a decrease of his/her performance may occur (Wageman, Gardner \& Mortensen, 2012).

O'Leary et al. (2011) propose several 
hypotheses on the impact that multiple team memberships (MTM) has on productivity. (O’Leary, Mortensen \& Wooley, 2011). To find out whether there already is empirical support for the hypotheses proposed by O'Leary et al. (2011), a literature search was conducted using Google Scholar, Web of Science and Proquest and papers that have cited O'Leary et al. were identified and reviewed. There were 44 forward citations found in Google Scholar, 15 in Web of Science and 20 in Proquest. However, no empirical evidence using quantitative research methods was found in empirically proving O'Leary et al. (2011) models. Maynard, Gilson and Mathieu (2012) also performed a literature review and found that there is a lack of empirical studies examining the impact of multiple team member- ship (MTM) on performance. In sum, on the one hand, we observe a growing prevalence of the involvement of individuals simultaneously in multiple teams, whereas on the other hand there is limited empirical evidence of the performance effects of MTM. This article contributes to closing this gap in the literature on MTM.

This leads to the main research question: To what extent does MTM impact on individual and team performance? The aim of this paper is to provide empirical evidence for a number of untested hypotheses proposed by O'Leary et al. (2011) regarding the impact of MTM on performance at the individual and team level.

\section{2}

\section{Theoretical framework and hypotheses}

The first proposition developed by O'Leary et al. (2011:468) reads:

"Proposition 1: The relationship between the number of teams individuals are members of and productivity at the individual and team levels is curvilinear; the positive relationship increases at a decreasing rate and eventually turns negative".

O'Leary et al. (2011) theorised that up to a certain point the higher the number of teams an individual is concurrently a member of, the more he/she is able to focus on the main tasks that are key priorities to him/her and due to this focus, work can be done more efficiently. However, when above a moderate level, the individual may experience temporal misalignment which causes the work in the different project teams to be done asynchronously and the increase of queue time can offset the individual's work efficiency. The authors defined productivity at the individual and team level as "the ability to create products or services that meet the expectations of key stakeholders in a given time period with a given set of human and other resources" (O'Leary et al., 2011:466; cited from Adler et al., 2009). In this paper, individual productivity is seen as one of the many dimensions of individual job performance. The project teams in this study are engineeringrelated and technology driven, thus team members often encounter complex problems that need to be solved innovatively. Individuals with high innovative performance can be seen as an indication of how well they are able "to exceed their standard work behaviours by generating, promoting and realizing new ideas" (Janssen, 2001:1042). By engaging in multiple teams concurrently, the individual may encounter more diverse sources of ideas across all teams and thus he/she is inspired to solve problems in more innovative ways. As the number of multiple team memberships increases however, an individual is overloaded with work. This may result in the individual being more focused on getting the job done (i.e. standard work behaviours) and less time is available to share ideas with other team members in order to find a creative way to 'exceed their standard work'. Consequently, our first hypothesis reads:

Hypothesis 1: The relationship between the number of multiple team memberships that an individual has and the individual innovative performance is curvilinear; the positive relationship increases at a decreasing rate and eventually turns negative.

Project team performance is commonly seen as the adherence to quality, time and budget, and the (business) objective (de Wet, 1988). When members in a specific focal team concurrently have multiple memberships with other teams, this may allow the team members to integrate the diverse sources of knowledge and resources into the focal team so that the focal team's performance can be improved. 
Beyond the moderate level, the more multiple team memberships a team's members have, the less time they have to discuss new ideas and/or integrate the resources they have obtained in other teams. Moreover, they may experience temporal misalignment individually and thus the focal team's performance is affected by the accumulation of these misalignments as they create coordination problems. This leads to hypothesis 2 :

Hypothesis 2: The relationship between the number of multiple team memberships that a focal team's members have concurrently with other teams and team performance is curvilinear; the positive relationship increases at a decreasing rate and eventually turns negative.

In the human resource (HR) literature, personnel selection for teams is frequently based upon competencies of the workers such as their education and experience because they are believed to have an impact on job performance (Medoff \& Abraham, 1980; McDaniel, Schmidt \& Hunter, 1988). Empirical evidence shows that competencies of workers yield superior work performance (Spencer \& Spencer, 1993). McDaniel et al. (1988:329) found, for example, that "for all levels of job experience and for both low- and high-complexity jobs, the correlation between job experience and job performance is positive". When facing new challenges, an experienced person is able to relate the new experience to his/her past experience in order to identify potential risks and work through these challenges more effectively (Jansen et al., 2013). In the project management literature, lessons learnt through previous experience in projects are important so that similar mistakes can be avoided and the best practices can be implemented (Camilleri, 2011). A higher level of education is an indication that a person not only has more general knowledge but also possesses specialised knowledge if he/she pursues further into his/her professional field (Piazza-Georgi, 2002). Singer and Bruhns' study (1991) found that educational qualifications significantly predict performance in certain skilled occupations. From the above arguments, Hypotheses 3 and 4 are proposed as follows:

Hypothesis 3: Project experience positively impacts individual innovative performance.

Hypothesis 4: Level of education positively impacts individual innovative performance.
Besides experience and education level, individual skills have been positively associated with performance (Spencer \& Spencer, 1993; Hartle, 1995; Sandberg, 2000). In this study, three skills are considered to be important for innovative performance, namely: emotional skills, cognitive skills and social skills.

\section{Emotional skills}

Côté and Miners (2006:4) conceptualised emotional intelligence (EI) as "the ability to grasp and reason correctly with emotional abstractions (emotional concepts) and solve emotional problems". Emotional skills allow an individual to regulate their emotions, especially under stressful situations, so that they can perform effectively in teams (Lopes et al., 2006). While working with others in a team, individual team members engage in interpersonal conflict, an important work related stressor and research to date shows that effective emotional regulation, buffers against the negative effects of intra-team conflict (Curşeu, Boroş \& Oerlemans, 2012). Moreover, emotional intelligence allows individuals to foster a heuristic way of processing information by using the automatic process of cognition. Thus information is processed quickly due to the heuristic type of reasoning (Curşeu, Vermeulen \& Bakker, 2008). Positive emotions are useful for creative tasks (Isen, Daubman \& Nowicki, 1987). Day and Carroll (2004) argue that although there are many (unpublished) studies that claim that there is a strong correlation between EI and job performance, there is unfortunately little empirical support for the claim. To test this claim, Hypothesis 5 reads:

Hypothesis 5: Emotional skills positively impact on individual innovative performance.

\section{Cognitive skills}

Individuals working in engineering-related project teams deal with tasks that are technological complex. Cognitive skills are thus necessary as they allow individuals to gain knowledge of facts, procedures and rules that are necessary to perform the technical core of their job (Côté $\&$ Miners, 2006). Moreover, studies have shown that people with cognitive skills are able to develop techniques and strategies to obtain the required information from the external environ- 
ment (Verplanken, Hazenberg \& Palenewen, 1992; Xie, 2000). Curşeu (2011:415) cites from other studies and mentiones that individuals with need of cognition are "better in solving complex problems" (Bertrams \& Dickhäuser, 2009); "invest more cognitive resources in information processing" (Fleischhauer et al., 2010); "are rational in their decision making style" (Curşeu, 2006) and "tend to seek, acquire, think about and reflect on relevant information when solving cognitive tasks" (Coutinho, Wiemer-Hastings, Skowronski \& Britt, 2005). Based on the above theoretical arguments Hypothesis 6 is proposed:

Hypothesis 6: Cognitive skills positively impact on individual innovative performance.

\section{Social skills}

Interdependence amongst members in a team may result in conflicts and thus social skills are important for individuals to coordinate and integrate their work (Morgeson, Reider \& Campion, 2005). Individuals with social skills are able to accumulate more social capital (Glaeser, Laibson \& Sacerdote, 2002) which is beneficial for work performance (Thompson, 2005; Ellinger et al., 2011). When an individual is well-connected to other actors, he/she is able to gain social capital which exists in these relationships. From these ties, one is able to obtain diverse knowledge and/or information, share understanding and build trust with the others (Adler \& Kwon, 2002; Daniel, Schwier \& McCalla, 2003). Hence, Hypothesis 7 reads:

Hypothesis 7: Social skills positively impact on individual innovative performance.

The above seven hypotheses form the research model that this study is exploring empirically. This research model is shown in Figure 1.

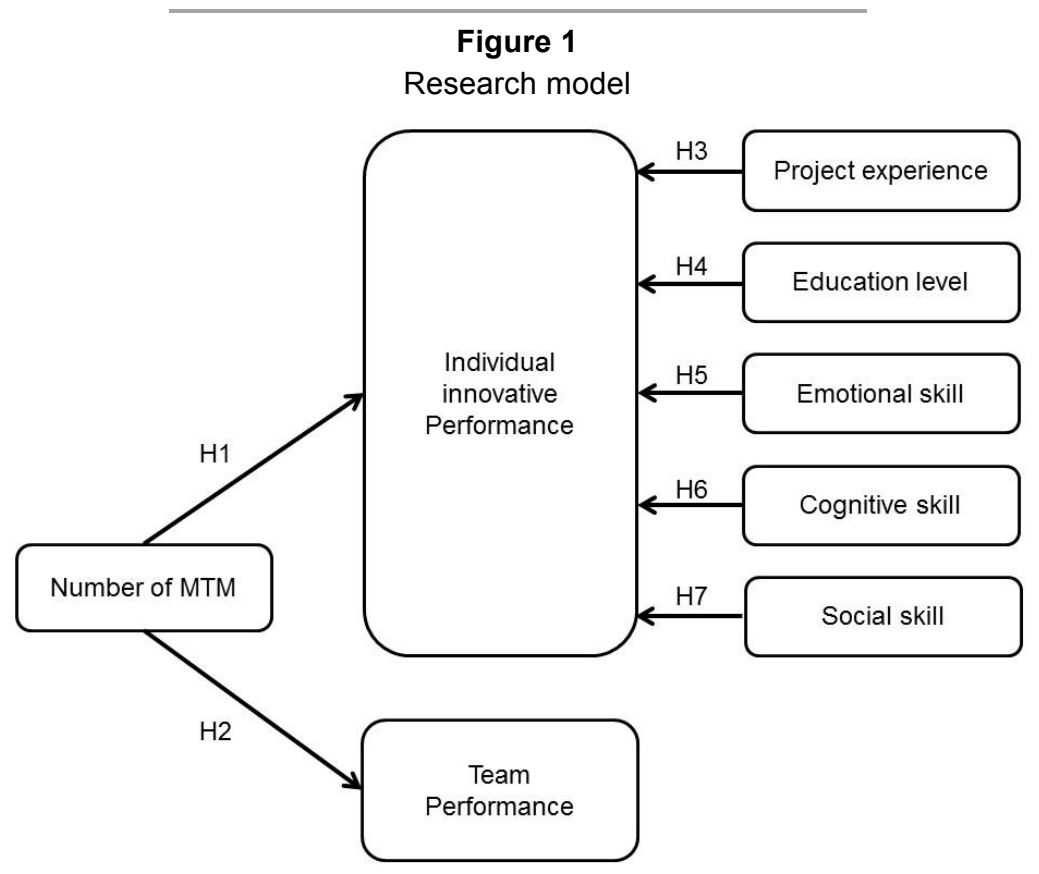

\section{3}

\section{Research methodology}

\subsection{Sample and data collection process}

In this study, data were collected from temporary project teams that conducted engineering- related tasks and in which engineers formed a substantial part of the team. A total of 88 individuals (who are part of a post graduate course in project management at a South African university) involved in projects in their own work environment were identified as field operators to help with data collection for this 
research. Among them 50 were project leaders of their own project teams. These field operators were subsequently requested to identify project teams with the following criteria and collect data from the team:

- A project team that the field operator is mostly involved in.

- The field operator is preferably (but not necessarily) the team leader.

- The size of the project team is less than 30 people.

- The project team has already completed 50 per cent or more of its activities; and

- The field operator may choose a project team that consists of team members from his/her own organisation or a mixture of team members from other organisations.

After the field operator has decided which project team he/she would like to collect data from, he/she needs to identify at least 5 core team members as respondents for questionnaires. Core team members are defined as those who are responsible for most of the activities which are important for the team task. Initial recruitment consists of 88 project teams from 88 different companies, comprising 455 team members.

The field operator sent out emails assuring anonymity and inviting the targeted respondents to fill in an online questionnaire. After the data collection period (one month) had ended, a total of 437 team members from 86 project teams returned completed questionnaires. Teams with less than three team members were dropped (based on a response criterion as suggested by Zhang, Hempel Han \& Tjosvold, 2007). This results in a sample consisting of 85 project teams corresponding to a 98.8 per cent team-level response rate, with 435 team members (95.6 per cent individual-level response rate).

\subsection{Measures and construct validation}

Constructs for performance at individual- and team-level were measured with existing scales. Details of the items used and the scale reliability are summarised in Appendix 1. In this section, when constructing our measurements we used only variables with multiple items as discussed in terms of literature sourced, as well as the reliability statistics (Cronbach's alphas) of the scales used.

\subsubsection{Dependent variables}

Individual innovative performance

In this study, individual innovative performance was measured using the nine items proposed by Janssen ((2001); Cronbach's alpha is 0.85 in his study). These items were based on Scott and Bruce's (1994) scale for individual innovative behaviour in the workplace, which draws on Kanter's (1998) work on the stages of innovation, namely, idea generation, idea promotion and idea realization. The Cronbach's alpha in this study was 0.94 for members' self-rated individual innovative performance. Cronbach's alpha of 0.6 was used as a threshold value which suggests that this variable can be measured with a single, uni-dimensional latent construct.

\section{Team performance}

Team performance in project environments is commonly measured with three criteria: (technical) quality, schedule performance and cost performance (Keller, 2006; Chiocchio, 2007; Rousseau \& Aubé, 2010). McComb et al. (1999) used 12 items (originally developed by Green, Welsh \& Dehler, (1992)) which included these three commonly used criteria in measuring project team performance. These data were collected from the team members. In this study, the reliability of this scale was (Cronbach's alpha of) 0.867 , indicating a reliable scale.

\subsubsection{Independent variables}

Three independent variables have constructs with multiple items: emotional, cognitive and social skills. Emotional skills are measured by seven items, which were used by Barchard and Hakstian (2004) to measure "ability emotional intelligence" (emotional skill). The Cronbach's alpha found in this study is 0.670 . Cognitive skills are conceptualized as "need for cognition" and based on the literature by Cacioppo, Petty and Kao (1984). Five items were used and this measure is reliable (Cronbach's alpha is 0.614 ). The concept of "social sensitivity" is used to measure social skills. It is defined as "verbal listening skill, but also ability to read social situations, and general knowledge of social rules and norms" (Riggio \& Reichard, 2008). The five items were highly reliable (Cronbach's alpha of 0.851 ) to measure this theoretical construct. 


\subsection{Level of analysis and measurement equivalence}

The data features in this study are multi-level in which the individuals (first level) were nested in the team (second level) they belonged to. It is important to statistically verify the reliability of aggregating the individual scores as team-level performance and learning (Bliese, 2000). Both Interrater Agreement Index, rwg(j) and Intraclass Correlation Coefficients (ICCs) are examined. $\operatorname{Rwg}(\mathrm{j})$ is an indication whether there is within-team agreement (James, Demaree \& Wolf, 1984). Median $\operatorname{rwg}(\mathrm{j})$ was 0.95 for team performance. The median $\operatorname{rwg}(\mathrm{j})$ were all greater than 0.70 which indicates a strong withinteam agreement (LeBreton \& Senter, 2008). Hence the individual responses could be aggregated to the team level analysis (Janz, Colquitt \& Noe, 1997). In addition to the agreement measure using rwg(j), the two multilevel reliability measures ICC(1) and ICC(2) were examined, using oneway analysis of variance on the individuallevel data. ICC is defined as "the measure of the relative homogeneity of the scores within the classes in relation to the total variation" (Haggard 1958: 6). These two measures show the extent to which group membership accounted for members rating (Bliese, 2000). ICC(1) provides an estimate of the group-level properties of the data unbiased by either group size or number of groups in the sample (James, 1982; Bliese \& Halverson, 1998). The team sizes were different, thus $\mathrm{k}$ was calculated with a formula recommended by Bliese and Halverson (1998). ICC(1) was 0.43 for team performance. According to Bliese (2000), ICC(1) of greater than 0.1 shows reliability, thus the ICC(1) scores in this study supported the aggregation. ICC(2) provides an estimation of the reliability of mean differences across teams (Bliese \& Halverson, 1998). The value is 0.79 for team performance. This score indicates that the teams can be reliably differentiated in terms of team performance.

\section{4}

Results

\subsection{Descriptive statistics}

Means, standard deviation as well as the correlation matrix associated with the variables in this study are presented in Table 1.

Table 1

Descriptive data (means and standard deviations) and intercorrelation amongst the variables

\begin{tabular}{|c|c|c|c|c|c|c|c|c|c|c|c|c|c|c|}
\hline Variables & $\mathbf{N}$ & Min & Max & Means & SD & \multicolumn{9}{|c|}{ Intercorrelation coefficients } \\
\hline \multicolumn{6}{|l|}{ Individual level } & 1 & 2 & 3 & 4 & 5 & 6 & 7 & 8 & 9 \\
\hline $\begin{array}{l}\text { 1. Innovative } \\
\text { performance }\end{array}$ & 414 & 1.78 & 7 & 5.28 & 1.10 & & & & & & & & & \\
\hline 2. Age & 429 & 21 & 74 & 36.73 & 10.03 & $(.029)$ & & & & & & & & \\
\hline 3. Gender & 426 & 1 & 2 & 1.77 & 0.42 & .006 & $.307^{*}$ & & & & & & & \\
\hline 4. Emotional skill & 420 & 2 & 5 & 3.70 & 0.60 & $.291^{*}$ & .059 & $(.018)$ & & & & & & \\
\hline 5. Cognitive skill & 421 & 2 & 5 & 4.12 & 0.62 & $.285^{\star}$ & $(.063)$ & .064 & $.396^{*}$ & & & & & \\
\hline 6. Social skill & 420 & 1 & 5 & 3.96 & 0.64 & $.174^{\star}$ & $(.033)$ & $(.099)$ & $.391^{*}$ & $.268^{*}$ & & & & \\
\hline 7. Project experience & 429 & 0 & 649 & 104.56 & 102.56 & $(.032)$ & $.752^{*}$ & $.234^{*}$ & .036 & $(.032)$ & $(.048)$ & & & \\
\hline 8. Education & 480 & 1 & 6 & 2.81 & 1.46 & .028 & .105 & .061 & .049 & .022 & .094 & .048 & & \\
\hline 9. Number of MTM & 429 & 0 & 17 & 3.54 & 3.12 & .078 & $.216^{*}$ & .098 & .055 & $(.061)$ & .019 & $.168^{*}$ & $(.026)$ & \\
\hline Team level & & & & & & 1 & 2 & 3 & 4 & 5 & 6 & 7 & & \\
\hline 1. Team performance & 85 & 2.43 & 4.90 & 3.72 & 0.49 & & & & & & & & & \\
\hline 2. Team tenure & 85 & 2 & 54.40 & 18.27 & 11.67 & $(.376)^{*}$ & & & & & & & & \\
\hline $\begin{array}{l}\text { 3. Team tenure } \\
\text { separation }\end{array}$ & 85 & 0 & 46.95 & 10.59 & 9.24 & $(.323)^{*}$ & $.637^{*}$ & & & & & & & \\
\hline 4. Team size & 85 & 3.4 & 30 & 9.25 & 5.35 & $(.103)$ & .122 & $(.057)$ & & & & & & \\
\hline 5. Education & 85 & 1.33 & 4.83 & 2.81 & 0.82 & $(.195)^{*}$ & $(.012)$ & $(.019)$ & $(.089)$ & & & & & \\
\hline $\begin{array}{l}\text { 6. Education } \\
\text { separation }\end{array}$ & 85 & 0 & 2.83 & 1.29 & 0.46 & .040 & .116 & .084 & $(.004)$ & $.357^{*}$ & & & & \\
\hline 7. Number of MTM & 85 & 0 & 44 & 14.24 & 8.90 & $.210^{*}$ & .058 & .059 & $(.029)$ & .017 & $(.145)$ & & & \\
\hline
\end{tabular}




\subsubsection{Individual level}

At the individual level, in the past six months respondents were on average involved simultaneously in 3.54 project teams (with a standard deviation of 3.12). The respondents are mainly male (76.7 per cent) and most of them are educated at a post-graduate level (average education level is close to 3 ). The average project experience that the respondents have is 8.71 years, but a large range exists (standard deviation of 8.55 years). Of the three skills measured, the respondents on average possess high cognitive skills (mean value of 4.12), followed by social skills (mean value of 3.96) and emotional skills (mean value of 3.70). When respondents self-rated their innovative performance, the average score is 5.28 (on a 7 points Likert scale).

Correlation statistics indicate that the emotional, cognitive and social skills have positive and statistically significant linear relationships with individual innovative performance ( $\mathrm{r}$ of 0.291 , 0.285 and 0.174 respectively). Correlations were found amongst the skills: emotional skill correlates with cognitive skill with correlation coefficient (r) of 0.396; and social skills correlate with emotional skill $(\mathrm{r}=0.391)$ as well as cognitive skill $(r=0.268)$. The variable of interest in this study, i.e. number of MTM, correlates positively with age $(\mathrm{r}=0.216)$ and project experience $(\mathrm{r}=0.168)$. It is not surprising that age and project experience have a strong and positive relationship $(\mathrm{r}=0.752)$. The size of the correlation coefficient reported above allows for the conclusion that no multicollinearity problems exist in our data.

\subsubsection{Project team level}

At the project team level, the average of team tenure is 18.27 months with a standard deviation of 11.67 months. On average, there are 9 core team members per project team. The diversity of teams is viewed in terms of separation in team tenure (standard deviation of team tenure of the team members in a team) and separation in education level (i.e. standard deviation of education level of the team members in a team). Looking at the separation of team tenure, the average is 10.59 months; whereas the education separation has a mean value of 1.29. This means that teams consist of team members who are diverse in term of their team tenures and education levels. The number of MTM per team is 14.24 projects on average (standard deviation of 8.90). The members in each team assessed their team's performance and the mean value is 3.72 indicating a quite high team performance (on a 5 point Likert scale).

From the correlation matrix, three control variables have negative linear relationships with team performance, namely: team tenure $(\mathrm{r}=-0.376)$, team tenure separation $(\mathrm{r}=-0.323)$ and education $(\mathrm{r}=-0.195)$. Number of MTM per team on the other hand has a positive and significant correlation with team performance $(\mathrm{r}=0.210)$.

\subsection{Multivariate regression analysis}

The models in this study are estimated by conducting Ordinary Least Square-based hierarchical regression analyses. All variables mentioned in the previous section are entered in the following steps:

\subsubsection{Individual level analysis}

Model 1 contains the control variables, including age and gender of the respondents. Next, in Model 2, emotional skills, cognitive skills, social skills, education level and project experience are added to test hypotheses 3 to 7. In Model 3, the number of MTM (mean centered) is entered to test linear relationship. To investigate Hypothesis 1, the curvilinear relationship between MTM and innovative performance at individual level, a squared term of number of MTM (mean centered) is entered in Model 4. Table 2 shows the results of the regression analyses.

In Table 2, with the exception of Model 1 (control variables only), all models have statistically significant F-values $(p<0.01)$ allowing for the conclusion that the proposed regression models fit the data. As a point of interest, in all models the control variables, age and gender do not impact significantly on individual innovative performance. The results presented in Model 2 show that emotional and cognitive skills explain for 12 per cent variance of individual innovative performance and indicated positive and statistically significant impacts implying that hypotheses 5 and 6are supported. In Model 4, the number of MTM that the respondent has showed a significant curvilinear relationship (beta coefficient $=-0.206$; 
$\mathrm{p}<0.01)$. Thus, hypothesis 1 is supported. The Variable Inflation Factor $(V I F)$ values associated with variables in the regression models were less than 10, indicating that no serious multicollinearity problems exist in these models.

Table 2

Multi team membership and individual innovative performance

\begin{tabular}{|c|c|c|c|c|}
\hline \multirow{2}{*}{ Variables } & \multicolumn{4}{|c|}{ Dependent variable: Individual innovative performance } \\
\hline & Model 1 & Model 2 & Model 3 & Model 4 \\
\hline $\begin{array}{l}\text { Constant } \\
\text { Control variables }\end{array}$ & $5.479^{x \times x}$ & $5.411^{\mathrm{m} *}$ & $5.454^{m *}$ & $5.652^{\mathrm{x} *}$ \\
\hline Age & -0.034 & -0.015 & -0.032 & -0.050 \\
\hline $\begin{array}{l}\text { Gender } \\
\text { Independent variables }\end{array}$ & 0.016 & 0.010 & 0.006 & -0.019 \\
\hline Emotional skills & & $0.199^{* * * *}$ & $0.193^{* * * *}$ & $0.206^{* * * *}$ \\
\hline Cognitive skills & & $0.192^{* * *}$ & $0.200^{* * *}$ & $0.205^{* \star *}$ \\
\hline Social skills & & 0.044 & 0.041 & 0.043 \\
\hline Project experience & & -0.022 & -0.024 & -0.012 \\
\hline Education & & 0.012 & 0.017 & 0.016 \\
\hline $\begin{array}{l}\text { Number of MTM } \\
\text { Number of } \text { MTM }^{2}\end{array}$ & & & 0.090 & $\begin{array}{l}0.253^{* *} \\
-0.206^{* *}\end{array}$ \\
\hline $\begin{array}{l}R^{2} \\
R^{2} \text { change } \\
F \text {-value } \\
F \text {-value change } \\
\text { VIF range }\end{array}$ & $\begin{array}{l}0.1 \% \\
0.1 \% \\
0.124 \\
0.124 \\
1.104\end{array}$ & $\begin{array}{l}12.2 \% \\
12.1 \% \\
4.431^{* * *} \\
6.148^{* * *} \\
1.024 \sim 2.455\end{array}$ & $\begin{array}{l}12.9 \% \\
0.8 \% \\
4.135^{* \star *} \\
1.930 \\
1.028 \sim 2.491\end{array}$ & $\begin{array}{l}14.5 \% \\
1.6 \% \\
4.185^{\star \star *} \\
4.128^{* *} \\
1.028 \sim 2.749\end{array}$ \\
\hline
\end{tabular}

$" p<0.10 ; " p<0.05 ; " \cdots p<0.01$

\subsubsection{Team level analysis}

Once again Model 1 contains the control variables, including team tenure, team tenure separation, team size, education and education separation. Next, the total number of MTM of all the members in the team (mean centered) is entered to test the linear relationship. To investigate hypothesis 2 , the curvilinear relationship between MTM and innovative performance at group level the squared term of number of MTM (mean centered) of the team is entered in Model 3. Table 3 shows the results of our empirical analyses.

Table 3

Multi team membership and team performance

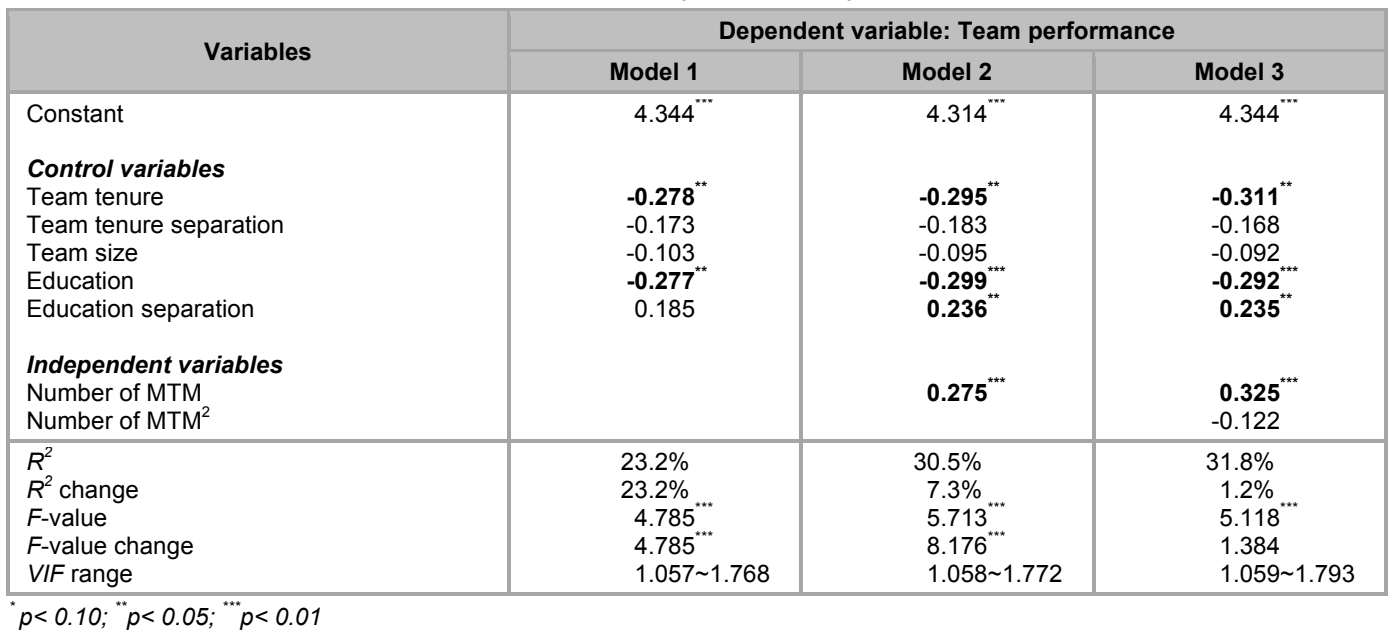


All the models have significant F-values $(p<0.01)$ indicating that the data fit the proposed regression models. The variables that account for the highest percentage of variance in team performance are the control variables team tenure and education in Model 1 , with a $R^{2}$ change equal to 23.2 per cent. Both control variables indicate a negative linear relationship with team performance. In model 2, the number of MTM is entered and it explains an additional 7.3 per cent of the variance in the dependent variable with a statistically significant beta coefficient of 0.275 . The squared form of number of MTM is entered in Model 3 and it does not show a statistically significant beta coefficient value. As a consequence, hypothesis 2 (curvilinear relationship) is rejected in this study. The results in Table 3 indicate that there is no curvilinear relationship between number of MTM and team performance, but a positive linear relationship between the two variables.

\section{5}

\section{Conclusion and recommendations}

Working in teams is regarded to be more effective than working individually especially when individuals are working on complex tasks (Hinsz, Tindale \& Vollrath, 1997). Within a multi-project-environment, scheduling human resources in simultaneous projects is inevitable. This implies that an individual may simultaneously work in multiple project teams. Having multiple team memberships concurrently (MTM) will impact on both the individual and the team's performance as suggested by O'Leary et al. (2011). This study was guided by the following research question: To what extent does MTM impact on performance at individual and team level? The aim of the research was to provide the empirical evidence to the first proposition developed by O'Leary et al. (2011): The relationship between the number of teams individuals are members of and performance at the individual and team levels is curvilinear; the positive relationship increases at a decreasing rate and eventually turns negative. In this section, the most important findings of this study are provided and some managerial recommendations as well as recommendations for future research are provided.
At the individual project team member level, this study provided the empirical evidence for an inverted-U shaped relationship between concurrent MTM and individual innovative performance. In other words, when an individual is simultaneously involved in multiple project teams, at first he/she will have higher individual innovative performance; however, there exists an optimal number of MTM and beyond this number, the individual innovative performance will start to decrease. O'Leary et al. (2011) stated that focused "attention on efficiency-oriented practices" explains the positive slope of the relationship, while fragmented attention" explains the negative slope of this curvilinear relationship. Other theoretical arguments for the negative relationship may be stress due to multiple demands from different project leaders (Wageman et al., 2012) and the decrease of high quality leader-member exchange (LMX) due to a stressful, dissatisfactory, and anxiety-provoking situation related to multiple LMX relationships in MTM (Alfaro, 2009). Besides MTM, this study also proposed several other factors that may impact on an individual's innovative performance, namely: project experience, education, emotional skills, cognitive skills and social skills. It was found that only emotional and cognitive skills of project team members had a positive impact on individual innovative performance. These two skills also correlate with one another $(\mathrm{r}=0.396)$. Curşeu and others (2008) stated that "emotion and cognition are linked into a single interdependent representational system" (cited from Forgas, 1995) where "positive emotional states strengthen judgements based on intuition, while negative emotions strengthen rational and analytical processes" (Curşeu et al., 2008:66). These two skills accounted for 12.1 per cent of the variance in the individual performance whereas MTM only accounts for 1.6 per cent. Effective coping strategies with task and teamwork related demands are plausible explanations for the positive effect of cognitive and emotional skills on individual work performance in project teams. Individuals scoring high on cognitive skills have a stronger task engagement, are more rational in their choices (Curşeu, 2006) and make better use of different others in the team as information sources, essential in the learning on the job process (Curşeu, 2011). 
Moreover, as working with others in a team often poses emotional challenges associated with conflict (Curşeu, Boroş \& Oerlemans, 2012), emotional skills are essential for coping with these challenges and as such are beneficial for individual performance. To conclude, group members scoring high on cognitive and emotional skills are likely to develop more effective strategies for coping with task and teamwork related demands and ultimately perform better than individual scoring low on cognitive and emotional skills.

At the project team level, the proposition formulated by O'Leary et al. (2011) did not find empirical support. Hypothesis 2 was rejected as the results showed a positive relationship rather than an inverted-U shape. This study supported the O'Leary et al. (2011) argument that when individuals gather lessons learnt from other teams, the focal team will be able to improve upon their work practices (e.g. more efficient routines, knowing more alternatives sources of resources needed) and thus improve team performance. However, this study did not find empirical evidence of the negative impact of too many MTM on team performance as O'Leary et al. (2011) argued that poor team performance is due to the introduction of lags/delays where one task of a member may be dependent on the task completion of another who is busy with tasks in another team. One of the explanations for this absence of negative slop can be that in multiple-project environment, a programme or portfolio manager is appointed to manage these simultaneous multiple projects. These managers need to have important competencies namely scheduling and staffing human resources, especially when facing the problem of resource constraints. To solve this problem, many advanced scheduling techniques are developed and applied; for example, a simulated annealing algorithm for the resourceconstrained project scheduling problem was developed by Bouleimen and Lecocq (2003). Thus, the problem of lags/delays can be eliminated for possible negative impact on team performance. In this study, the control variable education separation indicates how diverse teams are in terms of education level. This variable impacts positively on team performance. This result supports the compositional effect of teams on team performance.
From cognitive resource diversity theory, it can be derived that teams that consist of heterogeneous members reach higher performance levels because these members bring unique cognitive resources to the team (Horwitz, 2005). The other two control variables, team tenure and education, have significant and negative relationships with team performance. The team performance in this study is assessed by the team members. Those teams with a lower education level may not be able to critically assess the team or their perception of the team's performance is higher than their expectations; as a result they could over rate team performance. An explanation for the negative tenure effects is that newcomers in a group are more likely to possess proactive behaviours, such as changing work procedures, feedback seeking and networking (CooperThomas \& Burke, 2012). They may stimulate other members to revise their shared cognition about how to perform the tasks and thus improve group function and performance (Levine \& Choi, 2004).

The findings of this research have important implications for managerial practices, especially for programme or portfolio managers who manage multiple projects. In multi-project environment, scheduling human resources across simultaneous projects implies that an individual may be involved in more than one project teams at the same time. Managers should be aware of the possible positive and negative impacts of scheduling a person to involve simultaneously in too many or few project teams on his/her individual performance. If a large number of MTM is inevitable due to resource constraints, then the managers need to select members who have high emotional and cognitive skills as these two personal attributes have positive impacts on individual performance. If the managers apply good scheduling techniques, the problems of lags or delays do not occur amongst the projects; then the large number of MTM of a project team will result in high team performance. Lastly, managers could select team members with diverse jobrelated attributes, such as education level as was shown in this study, when composing project teams. Studies (e.g. Naranjo-Gil, Hartmann \& Maas, 2008; Van Dijk, Van Engen \& Van Knippenberg, 2012) have shown 
a positive association between educational diversity and team performance.

Some limitations in this study exist and these also shed some light on future research avenues. First, this study only tests one of the propositions proposed by O'Leary et al. (2011). Other propositions can be empirically tested so that the impact of MTM can be fully examined. For example, O'Leary et al. (2011) identified the other dimension of MTM, as "variety" (i.e. the diversity in tasks, technologies, locations, etc) of the teams that individuals are members of and that a focal team overlaps with. Second, individual performance is selfassessed; thus there might be a common method bias problem. In order to mitigate this problem, multisource measurement procedures can be used "where performance dimensions were treated as traits and raters or rater sources as methods" (Lance, Dawson, Birkelbach \& Hoffman, 2010). Third, this study focuses on engineering-related project teams. These project teams often face challenges such as technology complexity and the team's performance may be related to technology-related problems. Other type of projects with different tasks can be investigated so that the impact of MTM on performance can be examined without these technology-related factors. Finally, the impact of MTM on performance is examined at two levels, namely individual and team levels. For organisations that are project-based (so-called project-based organisations), the impact of MTM on performance at organisational level can be explored as well because pressures on teams, team members and their leaders might be more severe.

\section{Acknowledgement}

I wish to express my gratitude towards dr. Petre Curseu of the Department of Organization Studies at Tilburg University for his valuable suggestions for improving the paper. I also would like to thank Mr. Corro van Waveren of the Graduate School of Technology Management at University of Pretoria who has helped me throughout the data gathering process in South Africa.

\section{References}

ADLER, P., BENNER, M., BRUNNER, D., MACDUFFIE, J., OSONO, E., STAATS, B., TAKEUCHI, H., TUSHMAN, M. \& WINTER, S. 2009. Perspectives on the productivity dilemma. Journal of Operations Management, 27(2):99-113.

ADLER, P.S. \& KWON, S.-W. 2002. Social capital: prospects for a new concept. Academy of Management Review, 27(1):17-40.

ALFARO, I. 2009. The impact of multiple team memberships in leader-member exchange relationship (LMX). Proceedings of the 2009 international workshop on Intercultural collaboration. Palo Alto, California:195-198.

BARCHARD, K.A. \& HAKSTIAN, A.R. 2004. The nature and measurement of emotional intelligence abilities: basic dimensions and their relationships with other cognitive ability and personality variables. Educational and Psychological Measurement, 64(3):437-462.

BERTRAMS, A. \& DICKHÄUSER, O. 2009. High school students' need for cognition, self-control capacity and school achievement: Testing a mediation hypothesis. Learning and Individual Differences, 19(1): 135-138.

BLIESE, P.D. \& HALVERSON, R.R. 1998. Group size and measures of group-level properties: An examination of eta-squared and ICC values. Journal of Management, 24(2):157-172.

BLEISE, P.D. 2000. Within-group agreement, non-independence, and reliability: Implications for data aggregation and analysis. In K.J. Klein \& S.W.J. Kozlowski (eds.) Multilevel theory, research, and methods in organizations: foundations, extensions, and new directions (pp. 349-382). San Francisco, CA: JosseyBass/Pfeiffer.

BOULEIMEN, K. \& LECOCQ, H. 2003. A new efficient simulated annealing algorithm for the resourceconstrained project scheduling problem and its multiple mode version. European Journal of Operational Research, 149(2):268-281. 
CACIOPPO, J.T., PETTY, R.E. \& KAO, C.F. 1984. The efficient assessment of need for cognition. Journal of Personality Assessment, 48(3):306-307.

CAMILLERI, E. 2011.Project success: critical factors and behaviours. Burlinghton: Gower Publishing Limited.

CHIOCCHIO, F. 2007. Project team performance: a study of electronic task and coordination communication. Project Management Journal, 38(1):97-109.

CHUDOBA, K.M., WYNN, E., LU M. \& WATSON-MANHEIM, M.B. 2005. How virtual are we? Measuring virtuality and understanding its impact in a global organization. Information Systems Journal, 15(4):279.306.

COOPER-THOMAS, H.D. \& BURKE, S.E. 2012. Newcomer proactive behavior: Can there be too much of a good thing? In: C.R. Wanberg (ed.) Handbook of organizational socialization (pp. 56-77). Oxford, UL: Oxford University press.

CURŞEU, P.L., VERMEULEN, P.A.M. \& BAKKER, R. 2008. The psychology of entrepreneurial strategic decisions. In: P.A.M. Vermeulen \& P.L. Curşeu (eds.) Entrepreneurial strategic decision-making: A cognitive perspective (pp. 41-67). UK: Edward Elgar Publishing Ltd.

CURŞEU, P.L. 2006. Need for cognition and rationality in decision making. Studia Psychologica, 48(2): 141-156.

CURŞEU, P.L. 2011. Need for cognition and active information search in small student groups. Learning and Individual Differences, 21(4):415-418.

CURŞEU, P.L., BOROŞ, S \& OERLEMANS, L.A.G. 2012. Task and relationship conflict in short-term and long-term groups: the critical role of emotion regulation. International Journal of Conflict Management, 23(1):97-107.

CÔTÉ, S. \& MINERS, C.T.H. 2006.Emotional intelligence, cognitive intelligence, and job performance. Administrative Science Quarterly, 51(1):1-28.

COUTINHO, S., WIEMER-HASTINGS, K., SKOWRONSKI, J.J., \& BRITT, M.A. 2005. Metacognition, need for cognition and use of explanations during ongoing learning and problem solving. Learning and Individual Differences, 15(4):321-337.

DANIEL, B., SCHWIER, R.A. \& MCCALLA, G. 2003. Social capital in virtual learning communities and distributed communities of practice. Canadian Journal of Learning and Technology, 29(3):113-139.

DAY, A.L. \& CARROLL, S.A. 2004. Using an ability-based measure of emotional intelligence to predict individual performance, group performance, and group citizenship behaviours. Personality and Individual Difference, 36(6):1443-1458.

DE WET, A. 1988, Measurement of project success. International Journal of Project Management, 6(3): 164-170.

EDMONDSON, A.C. \& NEMBHARD, I.M. 2009. Product development and learning in project teams: The challenges are the benefits. Journal of Product Innovation Management, 26(2):123-138.

ELLINGER, A.D.. ELLINGER, A.E., BACHRACH, D.G. WANG, Y.-L., BAŞ, A.B.E. 2011. Organizational investments in social capital, managerial coaching, and employee work-related performance. Management Learning, 42(1):67-85.

FLEISCHHAUER, M., ENGE, S., BROCKE, B., ULLRICH, J., STROBEL, A. \& STROBEL, A. 2010. Same or different? Clarifying the relationship of need for cognition to personality and intelligence. Personality and Social Psychology Bulletin, 36(1):82-96.

FORGAS, J.P. 1995. Mood and judgment: the affect infusion model (AIM). Psychological Bulletin, 117(1): 39-66.

GLAESER, E.L., LAIBSON, D. \& SACERDOTE, B. 2002. An economic approach to social capital. The Economic Journal, 112(483):F437-F458.

GREEN, S.G., WELSH, M.A. \& DEHLER, G.E. 1992. A longitudinal investigation of the selection, management, and performance of technological innovation projects: a six year, multivariate study. Decision and Management Science Program, National Science Foundation, Grant SES-8519455.

HAGGARD, E. 1958. Intraclass correlation and the analysis of variance. New York: Dryden Press.

HARTLE, F. 1995. How to re-engineer your performance management process. London: Kogan Page. 
HINSZ, V.B., TINDALE, R.S., \& VOLLRATH, D.A. 1997. The emerging conceptualization of groups as information processors. Psychological Bulletin, 121(1):43-64.

HORWITZ, S.K. 2005. The compositional impact of team diversity on performance: Theoretical considerations. Human Resource Development Review, 4(2):219-245.

ISEN, A.M., DAUBMAN, K.A. \& NOWICKI, G.P. 1987. Positive affect facilitates creative problem solving. Journal of Personality and Social Psychology, 52(6):1122-1131.

JAMES, L. R. 1982. Aggregation bias in estimates of perceptual agreement. Journal of Applied Psychology, 67(2):219-229.

JAMES, L.R., DEMAREE, R.G. \& WOLF, G. 1984. Estimating within-group interrater reliability with and without response bias. Journal of Applied Psychology, 69(1):85-98.

JANZ, B.D., COLQUITT, J.A. \& NOE, R.A. 1997. Knowledge worker team effectiveness: The role of autonomy, interdependence, team development and contextual support variables. Personnel Psychology, 50(4):877-904.

JANSEN, R.J.G., CURŞEU, P.L., VERMEULEN, P.A.M., GEURTS, J.L.A. \& GIBCUS, P. 2013. Information processing and strategic decision-making in small and medium-sized enterprises: The role of human and social capital in attaining decision effectiveness. International Small Business Journal, 31(2): 192-216.

JANSSEN, O. 2001. Fairness perceptions as a moderator in the curvilinear relationship between job demands, and job performance and job satisfaction. Academy of Management Journal, 44(5):1039-1050.

KANTER, R. 1988. When a thousand flowers bloom: structural, collective, and social conditions for innovation in organizations. In B.M. Staw \& L.L. Cummings (eds.) Research in Organizational Behavior (pp. 169-211). Greenwich, CT: JAI Press.

KELLER, R.T. 2006. Transformational leadership, initiating structure and substitutes for leadership: a longitudinal study of research and development project team performance. Journal of applied psychology, 91(1):202-210

LANCE, C.E., DAWSON, B., BIRKELBACH, D.M \& HOFFMAN B.J. 2010. Method effects, measurement error, and substantive conclusions. Organizational Research Methods, 13(3):435-455.

LEBRETON, J.M. \& SENTER, J.L. 2008. Answers to 20 questions about interrater reliability and interrater agreement. Organizational Research Methods, 11(4):815-852.

LEVINE, J. M. \& CHOI, H.S. 2004. Impact of personnel turnover on team performance and cognition. In E. Salas \& S.M. Fiore (eds.) Team cognition: Understanding the factors that drive process and performance (pp. 153-176). Washington, DC: American Psychological Association.

LOPES, N., GREWAL, D. KADIS, J. GALL, M. \& SALOVEY, P. 2006. Evidence that emotional intelligence is related to job performance and affect and attitudes at work. Psicothema, 18:132-138.

MANNING, S. 2008. Embedding projects in multiple contexts - a structuration perspective. International Journal of Project Management, 26(1):30-37.

MAYNARD, M.T., GILSON, L.L. \& MATHIEU, J.E. 2012. Empowerment - fad or fab? A multilevel review of the past two decades of research. Journal of Management, 38(4):1231-1281.

MCDANIEL, M.A., SCHMIDT, F.L. \& HUNTER J.E. 1988. Job experience correlates of job performance. Journal of Applied Psychology, 73(2):327-330.

MEDOFF, J.L.\& ABRAHAM,K.G. 1980. Experience, performance and earnings. The Quarterly Journal of Economics, 95(4):703-736.

MORGESON, F.P., REIDER, M.H. \& CAMPION, M.A. 2005. Selecting individuals in team settings: the importance of social skills, personality characteristics, and teamwork knowledge. Personnel Psychology, 58: 583-611.

NARANJO-GIL, D., HARTMANN, F. \& MAAS, V. 2008. Top management team heterogeneity, strategic change and operational performance. British Journal of Management, 19(3):222-234.

O'LEARY, M.B., MORTENSEN, M., WOOLEY, A.W. 2011. Multiple team membership: A theoretical model of its effects on productivity and learning for individuals and teams. Academy of Management Review, 36(3):461-478.

O'LEARY, M.B., WOOLEY, A.W. \& MORTENSEN, M. 2011. Multiteam membership in relation to multiteam systems. In S.J. Zaccaro, M.A. Marks \& L.A. DeChurch (eds.) Multiteam Systems: An Organization Form for Dynamic and Complex Environments (pp. 141-172). New York: Routledge. 
PAYNE, J.H. 1995. Multiple simultaneous projects: a state-of-art-review. International journal of project management, 13(3):163-168.

PIAZZA-GEORGI, B. 2002. The role of human and social capital in growth: Extending our understanding. Cambridge Journal of Economics, 26(4):461-479.

RIGGIO, R.E. \& REICHARD, R.J. 2008. The emotional and social intelligences of effective leadership: An emotional and social skill approach. Journal of Managerial Psychology, 23(2):169-185.

ROUSSEAU, V.\& AUBÉ, C. 2010. Team self-managing behaviors and team effectiveness: the moderating effect of task routineness. Group \& Organization Management, 35(6):751-781.

SANDBERG, J. 2000. Understanding human competence at work: An interpretative approach. Academy of Management Journal, 43(1):9-25.

SCOTT, S.G. \& BRUCE, R.A. 1994. Determinants of innovative behavior: a path model of individual innovation in the workplace. Academy of Management Journal, 37(3):580-607.

SINGER, M.S. \& BRUHNS, C. 1991. Relative effect of applicant work experience and academic qualifications on selection interview decisions: a study of between-sample generalizability. Journal of Applied Psychology, 76(4):550-559.

SPENCER, L.M. \& SPENCER, S.M. 1993. Competence at work: models for superior performance. New York: Wiley.

THOMPSON, J.A. 2005. Proactive personality and job performance: a social capital perspective. Journal of Applied Psychology, 90(5):1011-1017.

VAN DIJK, H., VAN ENGEN, M.L. \& VAN KNIPPENBERG, D. 2012. Defying conventional wisdom: a meta-analytical examination of the difference between demographic and job-related diversity relationships with performance. Organizational Behavior and Human Decision Processes, 119(1):38-53.

VERPLANKEN, B., HAZENBERG, P.T. \& PALENÉWEN, G.R. 1992. Need for cognition and information search effort. Journal of Research in Personality, 26(2):128-136.

WAGEMAN, R., GARDNER, H. \& MORTENSEN, M. 2012. The changing ecology of teams: new directions for team research. Journal of Organizational Behavior, 33(3):301-315.

WHitTINGTON, R., PETTIGREW, A., PECK, S., FENTON, E. \& CONYON, M. 1999. Change and complementarities in the new competitive landscape: A European Panel Study, 1992-1996. Organization Science, 10(5):583-600.

XIE, H. 2000. Shifts of interactive intentions and information-seeking strategies in interactive information retrieval. Journal of American Society for Information Science, 51(9):841-857.

ZHANG, Z.-X., HEMPEL, P.S., HAN, Y.-L., TJOSVOLD, D. 2007. Transactive memory system links work team characteristics and performance. Journal of Applied Psychology, 92(6):1722-1730.

\section{Appendix 1}

Measurement(s) of variables

\begin{tabular}{|c|c|}
\hline \multicolumn{2}{|l|}{ Individual level } \\
\hline Control variables & Measurement / Item(s) \\
\hline Age & 2013 (the year when this research was conducted) minus the birth year of the respondent \\
\hline Gender & $1=$ female, $2=$ male \\
\hline Independent variables & Item(s) \\
\hline Education* & $\begin{array}{l}\text { What is the highest education degree you have obtained? (1) Doctor degree; (2) Masters degree; } \\
\text { (3) Honours degree; (4) Postgraduate diploma; (5) Bachelor's degree; (6) Diploma. }\end{array}$ \\
\hline Project experience & Total months that the respondent has been working on projects over his/her entire work experience. \\
\hline Emotional skills & $\begin{array}{l}\text { To what extent do you agree with the following statements about yourself when performing your } \\
\text { tasks in your team? (1) It is difficult for me to find the right words for my feelings; ( } 2 \text { ) I am often } \\
\text { confused about what emotion I am feeling; (3) Facing an emergency (endangering life or major } \\
\text { property) would make me nervous; (4) I am good at "reading" the inner feelings of others even in } \\
\text { highly stressful situations; (5) I can keep myself calm even in highly stressful situations; (6) Usually, } \\
\text { I know what it takes to turn someone else's boredom into excitement; (7) I try to think good thoughts } \\
\text { no matter how badly I feel. } \\
\text { ( } 5 \text { points Likert scale: } 1=\text { strongly disagree to } 5=\text { strongly agree) }\end{array}$ \\
\hline
\end{tabular}




\begin{tabular}{|c|c|}
\hline Cognitive skills & $\begin{array}{l}\text { To what extent do you agree with the following statements about yourself when performing your } \\
\text { tasks in your team? (1) I like to have the responsibility of handling a situation that requires a lot of } \\
\text { thinking; (2) I really enjoy a task that involves coming up with new solutions to problems; (3) I would } \\
\text { prefer complex to simple problems; (4) I like tasks that require little thought once I've learned them; } \\
\text { (5) Learning new ways to think doesn't excite me very much. } \\
\text { (5 points Likert scale: } 1 \text { = strongly disagree to } 5=\text { strongly agree) }\end{array}$ \\
\hline Social skills & $\begin{array}{l}\text { To what extent do you agree with the following statements about yourself when performing your } \\
\text { tasks in your team? (1) I can tell when one of my fellow team members is having trouble with } \\
\text { performing his/her tasks; (2) I am able to see when one of my team members is in a bad mood; (3) I } \\
\text { can tell how the other team members feel just by looking at their facial expression and/or gestures; } \\
\text { (4) I know when one of my teammates is not in his/her best mood; (5) I am able to put myself in } \\
\text { other's team members place. } \\
\text { ( } 5 \text { points Likert scale: } 1=\text { strongly disagree to } 5=\text { strongly agree) }\end{array}$ \\
\hline Number of MTM & $\begin{array}{l}\text { The total number of simultaneous intra-organisational and inter-organisational project teams that the } \\
\text { respondent has been involved extensively in the past } 6 \text { months. }\end{array}$ \\
\hline Dependent variables & Item(s) \\
\hline $\begin{array}{l}\text { Innovative } \\
\text { Performance }\end{array}$ & $\begin{array}{l}\text { To what extent do you have the following behaviours when performing the tasks assigned to you in } \\
\text { your team? (1) Creating new ideas for improvements; (2) Searching out new working methods, } \\
\text { techniques, or instruments; (3) Generating original solutions to problems; (4) Mobilizing support for } \\
\text { innovative ideas; (5) Acquiring approval for innovative ideas; (6) Making important organizational } \\
\text { members enthusiastic for innovative ideas; (7) Transforming innovative ideas into useful } \\
\text { applications; (8) Introducing innovative ideas into the work environment in a systemic way; (9) } \\
\text { Evaluating the utility of innovate ideas. } \\
\text { (7 points Likert scale: } 1=\text { never to } 7=\text { Always) }\end{array}$ \\
\hline \multicolumn{2}{|l|}{ Team level } \\
\hline Control variables & Item(s) \\
\hline Team tenure & The mean value of a group of team members' involvements (in months) in the project team. \\
\hline $\begin{array}{l}\text { Team tenure } \\
\text { separation }\end{array}$ & The standard deviation of a group of team members' involvements (in months) in the project team. \\
\hline Group size & Number of team members (including the core team members) in a team \\
\hline Education & The mean value of a group of team members' education levels \\
\hline Education separation & The standard deviation of a group of team members' education levels \\
\hline Independent variables & Item(s) \\
\hline Number of MTM & $\begin{array}{l}\text { The total number of simultaneous intra-organisational and inter-organisational project teams that a } \\
\text { group of team members have been involved extensively in the past } 6 \text { months. }\end{array}$ \\
\hline \multicolumn{2}{|l|}{ Dependent variables } \\
\hline Team performance & $\begin{array}{l}\text { To what extent do you agree with the following statements about your project team? (1) This project } \\
\text { team met all of its business goals; (2) This project team provided its expected commercial value to } \\
\text { the organization; (3) This project team completed its objectives to achieve its strategic value; (4) } \\
\text { This project team was able to overcome all technical hurdles; }(5) \text { This project team met all of its } \\
\text { technical objectives; (6) This project team provided a (technical) solution that can be implemented; } \\
\text { (7) This project team accomplished high quality of work; }(8) \text { This project is more costly than } \\
\text { expected*; (9) Estimated project costs have been adjusted multiple times*; (10) Actual project costs } \\
\text { are within original estimated costs; (11) This project is on time in terms of projected schedule (12) } \\
\text { Progress on this project is too slow*; (13) The project schedule is repeatedly adjusted*. } \\
\text { (5 points Likert scale: } 1=\text { strongly disagree to } 5=\text { strongly agree) }\end{array}$ \\
\hline
\end{tabular}

* Reverse coded 